Agnieszka Żywicka*

\title{
WSPÓŁCZESNY WYMIAR CENTRALIZACJI ADMINISTRACJI PUBLICZNEJ W POLSCE NA PRZYKŁADZIE ZMIAN W MODELU ORGANIZACYJNYM ADMINISTRACJI MIAR
}

\section{Uwagi ogólne}

Centralizacja i decentralizacja są nierozerwalnie połączone $\mathrm{z}$ procesem administrowania ujmowanym jako wykonywanie określonych prawem zadań państwa. Zasady te w modelowaniu organizacji administracji publicznej są pochodną przyjętego systemu ustrojowego państwa i bywają stosowane najczęściej łącznie, ale w różnym stopniu ${ }^{1}$. Jak twierdzi J. Starościak: „zarówno centralizacja jak i decentralizacja mają charakter względny. Względność decentralizacji i związana z tym względność centralizacji powoduje, że w żadnym ze współcześnie istniejących państw cywilizowanych nie można mówić o jakiejś administracji całkowicie zdecentralizowanej czy całkowicie scentralizowanej. Określenia te będą wyrażały raczej tendencje rozwojowe pewnego systemu administracji - ani system administracji scentralizowanej, ani system administracji zdecentralizowanej - nie jest systemem wybranym dowolnie. Są to systemy wypływające z pewnego

* Agnieszka Żywicka - doktor habilitowany nauk prawnych, Wydział Prawa, Adminsitracji i Zarządzania, Uniwersytet im. Jana Kochanowskiego w Kielcach.

1 P.A. Tusiński, Katalog i treść zasad prawa administracyjnego [w:] Prawo administracyjne, red. M. Zdyb, J. Stelmasiak, Warszawa 2016, s. 159. 
układu stosunków społecznych i ekonomicznych oraz zmierzające do odegrania w tym układzie właściwej im roli. Żaden z nich nie jest też celem samym w sobie"2.

W polskim ustroju administracyjnym występuje dualistyczny system administracji publicznej, w ramach którego wyróżnia się dwa podsystemy administracji: rządowej, opartej na zasadzie centralizacji, oraz samorządowej, o charakterze zdecentralizowanym. Zasadą ustrojową wyrażoną wprost w Konstytucji RP jest decentralizacja władzy publicznej w ustroju samorządu terytorialnego (art. 15 ust. 1). Ustawa zasadnicza przewiduje zatem prymat decentralizacji przy jednoczesnym zachowaniu centralizacji na szczeblu administracji rządowej.

W literaturze przedmiotu znacznie częściej i obszerniej omawiana jest problematyka decentralizacji, zwłaszcza w odniesieniu do jej sztandarowego przykładu - samorządu terytorialnego ${ }^{3}$. Trudno jest się temu dziwić, gdyż centralizacja była układem charakterystycznym dla organizacji administracji publicznej w okresie PRL-u, a jej model przybierał formę skrajną, blokującą w wielu przypadkach realizację zadań publicznych. Jak podaje J. Boć: „[...] w ustroju socjalistycznym była to niemal organiczna wartość w organizacji państwa"4. Scentralizowane struktury administracji w ograniczonych rozmiarach i nowej formie organizacji są nadal potrzebne dla realizacji głównych zadań państwa, można wobec tego stwierdzić, że stale istnieje potrzeba ich występowania w modelu polskiej administracji publicznej. Proces centralizacji i decentralizacji administracji publicznej jest zjawiskiem dynamicznym, uzależnionym od względów politycznych, gospodarczych i społecznych. Doskonałym tego przykładem jest administracja miar, która jako niezespolona administracja rządowa z racji swej natury ma

2 J. Starościak, Decentralizacja administracji, Warszawa 1960, s. 25; podobnie S. Cieślak, Praktyka organizowania administracji publicznej, Warszawa 2004, s. 36-37.

${ }_{3}$ Np. J. Starościak, Decentralizacja...; T. Rabska, Podstawowe pojęcia organizacji administracji [w:] System Prawa Administracyjnego, red. J. Starościak, t. 1, Ossolineum 1977, s. 259; M. Stahl [w:] System Prawa Administracyjnego, t. 6, Podmioty administrujace, red. R. Hauser, Z. Niewiadomski, A. Wróbel, Warszawa 2011, s. 84-87.

4 A. Błaś, J. Boć, J. Jeżewski, Administracja publiczna, Wrocław 2004, s. 179. 
charakter scentralizowany. Poziom centralizacji w obrębie struktur tej administracji ewaluuje na przestrzeni lat w wyniku kolejnych reform - w zależności od trendów politycznych i gospodarczych, z różnym skutkiem dla gospodarki.

W niniejszym opracowaniu przedstawione zostaną tendencje rozwojowe, które uwidoczniły się w strukturach organizacyjnych administracji miar implikowane ustawą z 23.03.2017 r. o zmianie ustawy - Prawo o miarach oraz ustawy o wojewodzie i administracji rządowej w województwie . Wymieniony akt normatywy wyraźnie ukazuje silne inklinacje centralizacyjne i dekoncentracyjne w układzie organizacyjnym administracji miar, które są uzasadniane potrzebami dostosowania jej struktur do współczesnych potrzeb gospodarki, rozwoju technologicznego oraz wpływem prywatyzacji zadań publicznych w obszarze usług metrologicznych. Zjawiska centralizacji i dekoncentracji występują w tym układzie organizacyjnym równolegle, co jest procesem typowym. W publikacji pominięte zostaną rozważania na temat układu organizacyjnego administracji miar przed transformacją polityczno-ustrojową z 1989 r., gdyż obecnie rozwiązania stosowane w poprzednim systemie straciły już znaczenie praktyczne.

\section{Współczesne rozumienie istoty centralizacji}

Problem centralizacji i decentralizacji zajmuje ważne miejsce w naukach o zarządzaniu, naukach politycznych, socjologii, ekonomii politycznej, mikroekonomii i naukach związanych z regionalistyką. W naukach prawnych centralizacja administracji ujmowana jest w dwóch znaczeniach. Po pierwsze, oznacza strukturę organizacyjną administracji, składającą się z kilku stopni organizacji, w której decyzje podejmowane są tylko przez organ centralny ${ }^{6}$, przy czym tak rozumiana centralizacja nie występuje w układach orga-

\footnotetext{
5 Dz.U. poz. 976.
}

6 S. Wrzosek [w:] Kompendium wiedzy administratywisty, red. S. Wrzosek, Lublin 2008, s. 43; Prawo administracyjne, red. M. Wierzbowski, Warszawa 2006, s. 95. 
nizacyjnych państw współczesnych ${ }^{7}$. W drugim znaczeniu - charakterystycznym dla współczesnych modeli organizacyjnych - jest to układ stosunków wewnętrznych administracji publicznej, w którym część zadań prowadzona jest tylko przez organy państwowe przy rozdziale od administracji samorządowej ${ }^{8}$. Dla zapewnienia jednolitości polityki i treści rozstrzygnięć wewnętrzne więzi organizacyjne między organami oparte są na zasadzie hierarchicznego podporządkowania, obejmującego możliwość wydawania dyspozycji ogólnych, indywidualnych poleceń i instrukcji szczegółowych oraz możliwość załatwiania spraw przez organ niższy, jak również bezpośrednie działanie organu zwierzchniego wobec najniższego organu w układzie organizacyjnym, z pominięciem organu na stopniach pośrednich ${ }^{9}$.

Do istotnych elementów współczesnej centralizacji J. Boć zalicza:

1) ścisłe wyodrębnienie prawne zadań i kompetencji na każdym stopniu organizacyjnym administracji;

2) możliwość ich dekoncentrowania na organy niższego stopnia;

3) zachowanie hierarchicznego podporządkowania w sferze realizacji tych kompetencji ${ }^{10}$.

Centralizacja ma gwarantować administracji rządowej takie wartości działania, które są nie do osiągnięcia w organizacjach zdecentralizowanych: szybkość postępowania, zdyscyplinowanie w zakresie realizacji określonego i konkretnego zadania, jednolitość decyzji, która może być podbudowywana elementem dyskusji i pomocy ze strony podmiotów niższego stopnia, kompetencje administracji rządowej w najważniejszych sprawach państwa i społeczeństwa, skuteczność decyzji podejmowanych w obrębie układu scentralizowanego. Prawna istota współczesnej centralizacji, gwarantująca sprawność układu scentralizowanego administracji publicznej, powinna iść w parze z dekoncentracją, wyrażać się zarówno w zapewnianiu sta-

\footnotetext{
${ }^{7}$ A. Błaś, J. Boć, J. Jeżewski, Administracja..., s. 178.

8 S. Wrzosek [w:] Kompendium..., red. S. Wrzosek, s. 43.

9 A. Błaś, J. Boć, J. Jeżewski, Administracja..., s. 178-179.

${ }^{10}$ A. Błaś, J. Boć, J. Jeżewski, Administracja..., s. 179.
} 
bilności rozdzielania kompetencji oraz przede wszystkim w możliwości ich przenoszenia na organy niższego stopnia ${ }^{11}$. Powyższe ustalenia w pełni odnoszą się do administracji miar.

\section{Modernizacja struktur organizacyjnych administracji miar}

Reforma systemu organizacyjnego administracji miar stanowi próbę rozwoju jej struktur ukierunkowanych na lepszą realizację nowych zadań publicznych w obszarze metrologii naukowej i transferu wiedzy do gospodarki, które przypadły do realizacji administracji miar w wyniku postępu technologicznego. W doktrynie sygnalizuje się, iż rozwój administracji polega na tworzeniu i wykorzystywaniu w sposób zorganizowany nowych możliwości oraz metod działania, lepszych od dotychczasowych w znaczeniu większej skuteczności, efektywności i przyjazności dla podmiotów administrowanych, a także na wprowadzaniu nowych rozwiązań organizacyjnych umożliwiających realizację powyższych działań ${ }^{12}$.

Jak twierdzi T. Rabska: „organizacja administracji podporządkowana jest ogólnym założeniom ustroju społeczno-politycznego. Nie można analizować organizacji w ogóle, w odizolowaniu od określonego typu administracji, bez uwzględnienia podłoża społecznego i ekonomicznego"13. Centralizacja jest związana z rzeczowym podziałem zadań administracji. Przyczyną centralizowania jest specjalizacja zadań i ich koncentracja w ośrodkach centralnych ${ }^{14}$. Analiza układu organizacyjnego administracji miar w kontekście problemu centra-

11 A. Błaś, J. Boć, J. Jeżewski, Administracja..., s. 52.

${ }_{12}$ M. Maciejewski, Rozwój i struktury rozwoju administracji [w:] Struktury administracji publicznej: metody, ogniwa, więzi, red. A. Mezglewski, t. 2, Rzeszów 2016, s. 54; J. Korczak, A. Pakuła, Prakseologiczna interpretacja zjawisk organizacyjnych [w:] A. Chrisidu-Budnik, J. Korczak, A. Pakuła, J. Supernat, Nauka organizacji i zarzadzania, Wrocław 2005, s. 123 i n.

13 T. Rabska, Podstawowe..., s. 259.

14 T. Rabska, Podstawowe..., s. 309. 
lizacji wymaga zatem odniesienia się do jej zadań publicznych i roli $\mathrm{w}$ aparacie administracyjnym państwa.

Administracja miar jest rządową, wyspecjalizowaną administracją gospodarczą, realizującą specyficzne obowiązki państwa w gospodarce rynkowej $\mathrm{w}$ dziedzinie metrologii. $\mathrm{Z}$ postanowień ustawy z 11.05.2001 r. - Prawo o miarach ${ }^{15}$ wynika, iż organy administracji miar realizują zadania w zakresie prawnej kontroli metrologicznej przyrządów pomiarowych oraz sprawują nadzór nad wykonywaniem przepisów niniejszej ustawy, tym samym powołane są do zapewnienia jednolitości miar i wymaganej dokładności pomiarów wielkości fizycznych w Rzeczypospolitej Polskiej. Polska metrologia znajduje się pod silnym wpływem prawa międzynarodowego i unijnego. Proces implementacji dyrektyw unijnych z obszaru metrologii do krajowego porządku prawnego rozpoczął się w $2001 \mathrm{r}$. i nadal jest konsekwentnie kontynuowany. Dyrektywy unijne normują kwestie związane z ustanowieniem legalnych jednostek miar, zasadami prawnej kontroli metrologicznej wspólnymi dla wszystkich przyrządów pomiarowych, wymaganiami dla poszczególnych przyrządów pomiarowych ${ }^{16}$. Jednocześnie w odniesieniu do nowych przyrządów pomiarowych zachodzi proces prywatyzacji zadań publicznych przez zastępowanie tradycyjnej prawnej kontroli metrologicznej realizowanej przez administrację miar, procedurami systemu oceny zgodności, również regulowany na poziomie wspólnotowym. Utrzymanie spójności pomiarowej i powiązań polskiego systemu metrycznego z systemem międzynarodowym stanowi oczywiście obowiązek państwa w skali całego kraju, uzasadniający realizację zadań publicznych z tego zakresu w obrębie struktur scentralizowanych. W polskim ustroju administracji rządowej jest on wykonywany przez organy administracji miar.

15 Dz.U. z 2018 r. poz. 376 ze zm. - dalej jako: pr. miar.

${ }^{16}$ Najważniejsze dyrektywy normujące powyższe sprawy to: dyrektywa Rady nr 80/181/EWG z 20.12.1979 r. w sprawie zbliżenia ustawodawstw Państw Członkowskich odnoszących się do jednostek miar i uchylającą dyrektywę 71/354/EWG (80/181/ EWG) (Dz.Urz. UE L 39, s. 40, ze zm.); dyrektywa Parlamentu Europejskiego i Rady 2014/32/UE z 26.02.2014 r. w sprawie harmonizacji ustawodawstw państw członkowskich odnoszących się do udostępniania na rynku przyrządów pomiarowych (Dz.Urz. UE L 96, s. 149, ze zm.); dyrektywa Parlamentu Europejskiego i Rady nr 2009/23/WE z 23.04.2009 r. w sprawie wag nieautomatycznych (Dz.Urz. UE L 122, s. 6, ze zm.). 
Problem niedostosowania dotychczasowych struktur administracji miar do potrzeb gospodarki był podejmowany od wielu lat. Dotychczasowy model organizacyjny administracji miar był krytykowany jako nieprzystający do nowych zadań, które zostały jej powierzone do realizacji w sferze usług z obszaru metrologii naukowej, w której oprócz tradycyjnych zadań publicznych powstała potrzeba prowadzenia prac o charakterze badawczo-rozwojowym i transferu technologii metrologicznych do gospodarki ${ }^{17}$. W kręgach rządowych akcentowano, iż nowe zadania trudno jest ulokować w pionowym układzie scentralizowania administracji miar istniejącym do 31.12.2017 r., złożonym z trzech szczebli: organ centralny - Prezes Głównego Urzędu Miar, terenowe organy administracji miar - dyrektorzy okręgowych urzędów miar i naczelnicy obwodowych urzędów miar.

W modelu organizacyjnym administracji miar, według stanu na 31.12.2017 r., istnieje hierarchiczne podporządkowanie organów, przy jednoczesnej aktywnej pozycji organów niższych i podporządkowaniu całego aparatu administracyjnego przepisom prawnym oraz zastosowaniu weryfikacji stosunków wewnętrznych ogólnym zasadom kontroli. System ten jednak stracił wydolność wobec konieczności wykonywania przez administrację miar zadań innowacyjnych i prowadzenia badań naukowych.

Celem uczynienia przedpola do dalszych rozważań niezbędne jest ogólne nakreślenie schematu organizacyjnego tej administracji obowiązującego do 31.12.2017 r. Artykuł 12 pr. miar. stanowi, że Prezesa GUM powołuje i odwołuje Prezes Rady Ministrów na wniosek ministra właściwego do spraw gospodarki, spośród osób wybranych w drodze otwartego i konkurencyjnego naboru. Wiceprezesów powołuje i odwołuje, również w drodze otwartego i konkurencyjnego

17 Dziesięć lat temu minister właściwy ds. gospodarki jako organ nadzorujący administrację miar podjął działania mające na celu identyfikację i analizę problemów krajowego systemu metrologicznego oraz wypracowanie koncepcji zmian organizacyjnych. Służył temu opracowany przez T.J. Quinna na zlecenie Ministerstwa Gospodarki Raport na temat instytucjonalnych aspektów rozwoju metrologii w Polsce. Zarządzeniem Ministra Gospodarki z 24.05.2007 r. został powołany zespół ds. opracowania rozwiązań systemowych w zakresie organizacji i funkcjonowania miar. 
naboru, minister właściwy do spraw gospodarki na wniosek Prezesa. Prezesowi GUM podporządkowane są terenowe organy administracji miar: dyrektorzy okręgowych urzędów miar i naczelnicy obwodowych urzędów miar, nad którymi Prezes sprawuje nadzór i kontrolę w zakresie prawidłowości wykonywanych przez nich zadań ${ }^{18}$. Dyrektorzy są powoływani i odwoływani przez Prezesa GUM, zaś naczelników powołuje Prezes GUM na wniosek właściwych dyrektorów okręgowych urzędów miar ${ }^{19}$. W świetle art. 13 pr. miar. minister właściwy ds. gospodarki, w drodze rozporządzenia, tworzy i znosi okręgowe i obwodowe urzędy miar oraz określa ich obszar działania oraz siedziby, przy uwzględnieniu lokalnych potrzeb, rozwoju gospodarczego oraz tradycji poszczególnych województw i powiatów, jak również warunków ekonomicznych działania urzędów. Do 31.12.2017 r. funkcjonuje dziewięć okręgowych urzędów miar (mających siedziby w: Bydgoszczy, Gdańsku, Łodzi, Katowicach, Krakowie, Poznaniu, Szczecinie, Warszawie i Wrocławiu) oraz pięćdziesiąt osiem obwodowych urzędów miar ${ }^{20}$.

Nowela Prawa o miarach z 2017 r. wprowadziła dwie istotne zmiany w układzie organizacyjnym administracji miar. Po pierwsze, zlikwidowano trójszczeblowość na rzecz dwóch szczebli przy zachowaniu pozostałych więzów organizacyjnych w tym aparacie, tym samym podnosząc przejrzystość hierarchicznego podporządkowania w obrębie jej struktur. W świetle zmienionego art. 10 pr. miar. od 1.01.2018 r. organami administracji miar są: Prezes Głównego Urzędu Miar, będący centralnym organem administracji, i dyrektorzy okręgowych urzędów miar. Zlikwidowano trzeci szczebel - naczelników obwodowych urzędów miar. Po drugie, przy Prezesie GUM powołano jednostkę o charakterze pomocniczym - Radę Metrologii, która wprawdzie nie wchodzi w skład struktur organizacyjnych administracji miar, lecz

${ }^{18}$ K. Stanik-Filipowska [w:] Administracja publiczna, red. B. Szmulik, K. Miaskowska-Daszkiewicz, t. 2, Ustrój państwowej administracji terenowej, Warszawa 2012, s. 533 .

${ }^{19}$ K. Stanik-Filipowska [w:] Administracja..., s. 533.

${ }^{20}$ Rozporządzenie Ministra Gospodarki z 19.03.2010 r. w sprawie zniesienia niektórych obwodowych urzędów miar oraz określenia obszaru działania i siedzib okręgowych i obwodowych urzędów miar (Dz.U. Nr 56, poz. 341). 
ma kompetencje opiniodawcze i weryfikacyjne z zakresu metrologii naukowej ${ }^{21}$. Przyjęte rozwiązanie można potraktować jako przejaw dekoncentracji niektórych zadań administracji miar na struktury akcesoryjne.

U podstaw budowania struktur organizacyjnych administracji publicznej leży potrzeba podziału pracy w toku administrowania. Jeżeli więcej zadań jest do spełnienia, większa jest specjalizacja zarówno terytorialna, jak i rzeczowa, co skutkuje powoływaniem większej liczby jednostek działających ${ }^{22}$. Naturalną konsekwencją centralizacji jest wobec powyższego dekoncentracja zadań publicznych w terenie. W wyniku reformy zwiększono poziom centralizacji struktur administracji miar, proces dekoncentracji zadań przeprowadzono w obrębie dwóch stopni organizacyjnych. Z prakseologicznego punktu widzenia powyższe rozwiązanie ujednolica i tak nadal bardzo rozbudowaną strukturę aparatu administracji niezespolonej w Polsce. Wprowadzone zmiany są zatem ze wszech miar uzasadnione. Zamiast obwodowych urzędów miar zostały utworzone wydziały zamiejscowe okręgowych urzędów miar, o których utworzeniu i siedzibach decyduje minister właściwy ds. gospodarki, biorąc pod uwagę zapotrzebowanie na usługi metrologiczne i tradycję w tym zakresie na danym obszarze. Paradoksalnie, centralizacja i dekoncentracja po zmianach ustrojowych może jednak negatywnie wpływać na szybkość realizowanych zadań przez administrację miar, wydłużając czas załatwiania tradycyjnych spraw z zakresu metrologii technicznej w terenie. Należy w tym przypadku uwzględnić osobliwy charakter zadań publicznych realizowanych przez administrację miar, których przebieg znacznie odbiega od przebiegu klasycznej sprawy administracyjnej. Integralną częścią postępowania w sprawie prawnej kontroli metrologicznej przyrządów pomiarowych są czasochłonne badania techniczne w laboratoriach lub w miejscu użytkowania przyrządów pomiarowych. Dzięki istnieniu rozbudowanego trójstopniowego systemu terenowych organów administracji miar przedsiębiorcy mieli dość dobry dostęp do organów wydających decyzje administracyjne w sprawie prawnej

\footnotetext{
${ }^{21}$ Art. 10a znowelizowanego Prawa o miarach.

${ }^{22}$ T. Rabska, Podstawowe..., s. 305.
} 
kontroli metrologicznej (mam tu na uwadze naczelników obwodowych urzędów miar). Obecnie te proporcje mogą ulec zachwianiu, gdyż organów właściwych do załatwiania najbardziej powszechnych spraw z zakresu metrologii - legalizacji ponownej przyrządów pomiarowych ${ }^{23}$, będzie dziewięć, a nie jak dotychczas sześćdziesiąt siedem. Centralizacja może zatem powodować niekiedy trudności w dostępie do organów administracji miar. Rozpatrując problem na płaszczyźnie efektywnego i elastycznego gospodarowania personelem w ramach struktur okręgowych urzędów miar, centralizacja struktur usprawni ten proces, przez stworzenie podstaw prawnych do czasowego delegowania pracowników do kontroli podmiotów gospodarczych działających na obszarze innych wydziałów, adekwatnie do faktycznego i aktualnego zapotrzebowania na czynności metrologiczne.

Prawna istota centralizacji obejmuje nie tylko stabilność w zakresie rozdziału kompetencji, ale i możliwość ich przenoszenia na organy niższego stopnia oraz weryfikację prawidłowości wykonywanych zadań przez organ centralny ${ }^{24}$. Trójstopniowość administracji miar w praktyce życia gospodarczego, jak już zaznaczono powyżej, wpływała pozytywnie na szybkość i sprawność załatwiania spraw, zwłaszcza dotyczących prawnej kontroli metrologicznej przyrządów pomiarowych oraz nadzoru metrologicznego (kontrole metrologiczne). W zasadzie dekoncentracja odbywała się z poziomu organu centralnego - Prezesa GUM równolegle na dwa niższe szczeble administracji miar ${ }^{25}$. Kompetencje naczelników obwodowych urzędów miar były w wielu przypadkach tożsame z kompetencjami dyrektorów okręgowych urzędów miar, różnił się czasem jedynie zakres rzeczowy. Przekazywanie kompetencji z poziomu dyrektorów okręgowych urzędów miar na naczelników obwodowych urzędów miar

${ }^{23}$ Szerzej na temat prawnej kontroli metrologicznej przyrządów pomiarowych i rodzajów tej kontroli A. Żywicka, Prawna kontrola metrologiczna jako szczególny instrument oddziaływania państwa na gospodarkę [w:] Prawne instrumenty oddziaływania na gospodarkę, red. A. Powałowski, Warszawa 2016, s. 666-677.

24 A. Błaś, J. Boć, J. Jeżewski, Administracja..., s. 180.

${ }^{25}$ Dyspozycję ustawową do dekoncentracji zadań w zakresie prawnej kontroli metrologicznej zawierają art. 8 b pr. miar., a w odniesieniu do nadzoru metrologicznego art. 21 i n. tegoż aktu. 
polegało na cedowaniu tożsamych uprawnień, ale w odniesieniu do poszczególnych rodzajów przyrządów pomiarowych, co tworzyło fikcję prawną w zakresie funkcjonowania mechanizmu dekoncentracji. Modernizacja systemu organizacyjnego administracji miar pozwoliła na wyeliminowanie błędów strukturalnych oraz wzmocniła nadzór organu centralnego nad prawidłowością wykonywanych zadań przez organy niższego stopnia ${ }^{26}$.

W świetle zarysowanego powyżej procesu centralizacji najważniejszym elementem przeprowadzonej reformy jest zastosowany mechanizm dekoncentracji kompetencji. Proces przekazywania kompetencji organom niższym jest podstawowym czynnikiem warunkującym sukces modernizacji systemowej. Ustawodawca, dokonując przekształceń struktur administracji miar, wprowadza dekoncentrację na poziomie dwóch szczebli. W ujęciu prakseologicznym proces dekoncentracji będzie przebiegał sprawniej, zlikwidowany został trzeci szczebel w strukturze organizacyjnej administracji miar. Organem przekazującym kompetencje dyrektorom okręgowych urzędów miar jest Prezes GUM. Z prakseologicznego punktu widzenia jest to rozwiązanie prawidłowe, trzeba jednak mieć na uwadze skutki reformy dla gospodarki już zasygnalizowane wyżej. Źle przeprowadzona dekoncentracja może czasem powodować wydłużenie terminów załatwiania spraw oraz osłabiać nadzór metrologiczny nad gospodarką. Można jednak wyrazić przekonanie, że w analizowanym przypadku dekoncentracja przyniesie pozytywne rezultaty, w postaci uelastycznienia procesu cedowania kompetencji, przez możliwość przekazywania przez Prezesa pewnych zadań dyrektorom okręgowych urzędów miar, bez względu na ich właściwość miejscową.

Niezwykle interesującym rozwiązaniem, z naukowego punktu widzenia, w nowym systemie organizacyjnym administracji miar w kontekście zjawiska centralizacji i dekoncentracji jest powołanie Rady

${ }^{26}$ W świetle znowelizowanego art. 12 ust. 6 pr. miar. Prezes GUM sprawuje nadzór w zakresie prawidłowości wykonywania przez dyrektorów zadań należących do zakresu działania i prawidłowości funkcjonowania kierowanych przez nich urzędów oraz przeprowadza w tym zakresie kontrole. 
Metrologii, a zwłaszcza jej powiązania strukturalne z administracją miar. Rada Metrologii stanowi przykład akcesoryjnej jednostki organizacyjnej administracji publicznej, o charakterze dopełniającym standardową konstrukcję aparatu administracyjnego, wydzielonym poza jej hierarchię zależności osobowej i służbowej. Przyjęte rozwiązanie wywołuje ważkie zmiany w sferze instytucjonalno-relacyjnej administracji miar ${ }^{27}$. Ustawodawca nie przyznał Radzie Metrologii osobowości prawnej ani statusu organu, nie ulokował jej również w układzie organizacyjnym administracji miar. Hierarchicznie Rada Metrologii podlega ministrowi właściwemu ds. gospodarki, została ukształtowana jako ciało kolegialne, stale funkcjonujące przy Prezesie GUM, w jej skład wchodzą powoływani przez ministra właściwego ds. gospodarki przedstawiciele organów administracji publicznej i agencji ściśle powiązanych z metrologią (przedstawiciele: ministra właściwego ds. gospodarki, ministra właściwego ds. nauki, Polskiego Komitetu Normalizacji, Polskiego Centrum Akredytacji, Wojskowego Centrum Metrologii), przedstawiciele środowiska gospodarczego prowadzącego badania w obszarze metrologii naukowej oraz przedstawiciel okręgowych urzędów miar. Ustawodawca wyposażył nowy podmiot w uprawnienia opiniodawcze (opiniowanie: stanu i kierunków rozwoju krajowej metrologii, działalności merytorycznej administracji miar, strategicznego planu działania Głównego Urzędu Miar, rocznych planów i sprawozdań Głównego Urzędu Miar) oraz quasi-weryfikacyjne (prawo wglądu do dokumentów administracji miar, przedkładanie sprawozdań i informacji o działalności administracji ministrowi właściwemu ds. gospodarki). Rolą nowej jednostki jest wspomaganie istniejących struktur administracji miar przez wzbogacanie o dodatkowe relacje $z$ otoczeniem gospodarczym i naukowym w zakresie działań innowacyjnych. Radzie zostały więc przyznane kompetencje w zakresie kształtowania kierunków rozwoju administracji miar i wspieranie w tym zakresie Prezesa GUM. Tym samym, dekoncentracja występuje poza struktury administracji miar, co jest zjawiskiem coraz częściej występującym w strukturach administracji rządowej, mającym na celu sprostanie

${ }^{27}$ Szeroko na temat akcesoryjnych struktur administracji publicznej wypowiada się P. Lissoń - zob. P. Lissoń [w:] Struktury..., red. A. Mezglewski, t. 2, s. 7-23. 
nowym zadaniom publicznym. Utworzenie Rady można potraktować jako element koordynacji działań różnych organów administracji publicznej w sferze metrologii.

\section{Podsumowanie}

Problematyka centralizacji i decentralizacji ma wymiar uniwersalny i ponadczasowy. Problem ten jest klasycznym tematem badawczym w ramach nauk o zarządzaniu, w szczególności w nauce o organizacji, jest też problemem centralnym w kontekście nieustającego, a być może w ogóle nierozstrzygalnego, sporu o rolę państwa w gospodarce. W wielu krajach, również w Polsce, dochodzi do zderzenia dwóch przeciwstawnych tendencji: $\mathrm{z}$ jednej strony chodzi o zachowanie sterowania centralnego, gdyż zapewnia ono ochronę interesów państwa, a także szansę na stopniowe wyrównywanie różnic między regionami. Z drugiej zaś strony uważa się, że pożądane byłoby stopniowe powiększanie zakresu decentralizacji ${ }^{28}$.

Konstatując, trzeba stwierdzić, że proces centralizacji i dekoncentracji jest zjawiskiem dynamicznym, o różnym nasileniu i różnym przebiegu, co można zaobserwować na przykładzie transformacji struktur administracji miar. Jest przykładem poszukiwania lepszych rozwiązań organizacyjnych, którym przyświeca cel zwiększania sprawności realizowanych zadań publicznych. Mimo powszechnej krytyki centralizacji można stwierdzić, że dla prawidłowego funkcjonowania struktur administracji rządowej nadal jest to najlepszy układ organizacyjno-strukturalny, który umożliwia realizację zadań publicznych wymagających jednolitości w skali całego kraju i jednakowej polityki państwa stosowanej wobec wszystkich podmiotów. Do takich obszarów zalicza się metrologia.

Przeprowadzone w strukturach administracji miar przekształcenia organizacyjno-strukturalne pozwalają rokować pomyślny rozwój tego

${ }^{28}$ S. Flejterski, M. Zioło, Centralizacja $i$ decentralizacja zadań publicznych w świetle wybranych rozwiązań europejskich. Próba oceny, „Studia Regionalne i Lokalne" 2008/3(33), s. 77. 
działu administracji gospodarczej. W wyniku reformy uporządkowano więzy hierarchicznej podległości organów i usprawniono mechanizm dekoncentracji kompetencji. Przyjęty sposób dekoncentracji pozwoli na lepsze wykorzystanie potencjału zasobów kadrowych administracji miar w gospodarce, co wydaje się obecnie najważniejszym celem ustawodawcy.

Kończąc rozważania, warto zauważyć, że administracja miar odgrywa istotną rolę w działalności gospodarczej przedsiębiorców będących producentami lub użytkownikami przyrządów pomiarowych wprowadzanych do obrotu gospodarczego. Metrologia jest uniwersalną dziedziną nauki i techniki, która przy odpowiednim wykorzystaniu jej możliwości porządkuje stosunki społeczno-gospodarcze, wspierając postęp naukowo-technologiczny i przyczyniając się do wzrostu gospodarczego i konkurencyjności gospodarki. Urzeczywistnienie powyższego celu mają zapewniać m.in. zasady organizacyjne administracji, spośród których zasadniczą jest scentralizowanie struktur, gwarantujące sprawność zarząazania odgórnie.

\section{Bibliografia:}

Administracja publiczna, t. 2, Ustrój państwowej administracji terenowej, red. B. Szmulik, K. Miaskowska-Daszkiewicz, Warszawa 2012

Błaś A., Boć J., Jeżewski J., Administracja publiczna, Wrocław 2004

Cieślak S., Praktyka organizowania administracji publicznej, Warszawa 2004

Flejterski S., Zioło M., Centralizacja i decentralizacja zadań publicznych wświetle wybranych rozwiąań europejskich. Próba oceny, „Studia Regionalne i Lokalne" 2008/3(33)

Kompendium wiedzy administratywisty, red. S. Wrzosek, Lublin 2008

Korczak J., Pakuła A., Prakseologiczna interpretacja zjawisk organizacyjnych [w:] A. Chrisidu-Budnik, J. Korczak, A. Pakuła, J. Supernat, Nauka organizacji i zarządzania, Wrocław 2005

Maciejewski M., Rozwój i struktury rozwoju administracji [w:] Struktury administracji publicznej: metody, ogniwa, więzi, red. A. Mezglewski, t. 2, Rzeszów 2016 Prawo administracyjne, red. M. Wierzbowski, Warszawa 2006 
Rabska T., Podstawowe pojęcia organizacji administracji [w:] System Prawa Administracyjnego, red. J. Starościak, t. 1, Ossolineum 1977

Starościak J., Decentralizacja administracji, Warszawa 1960 System Prawa Administracyjnego, t. 6, Podmioty administrujace, red. R. Hauser, Z. Niewiadomski, A. Wróbel, Warszawa 2011

Tusiński P.A., Katalog i treść zasad prawa administracyjnego [w:] Prawo administracyjne, red. M. Zdyb, J. Stelmasiak, Warszawa 2016

Żywicka A., Prawna kontrola metrologiczna jako szczególny instrument oddziatywania państwa na gospodarkę [w:] Prawne instrumenty oddziaływania na gospodarkę, red. A. Powałowski, Warszawa 2016 